\title{
Surfaces
}

\section{Simon During, Foucault and Literature: Towards a Genealogy of Writing (London and New York: Routledge, 1992), 259 pp.}

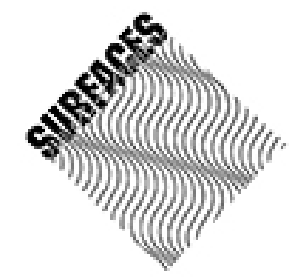

\section{Michael Hill}

Volume 2, 1992

URI : https://id.erudit.org/iderudit/1065241ar

DOI : https://doi.org/10.7202/1065241ar

Aller au sommaire du numéro

Éditeur(s)

Les Presses de l’Université de Montréal

ISSN

1188-2492 (imprimé)

1200-5320 (numérique)

Découvrir la revue

Citer ce compte rendu

Hill, M. (1992). Compte rendu de [Simon During, Foucault and Literature: Towards a Genealogy of Writing (London and New York: Routledge, 1992), 259 pp.] Surfaces, 2. https://doi.org/10.7202/1065241ar d'utilisation que vous pouvez consulter en ligne. 


\title{
BOOK REVIEW
}

SIMON DURING: FOUCAULT AND LITERATURE: TOWARDS A GENEALOGY OF WRITING

\author{
$\underline{\text { Michael Hill }}$
}

\section{Simon During, Foucault and Literature: Towards a Genealogy of Writing (London and New York: Routledge, 1992), 259 pp.}

Towards the end of Foucault and Literature Simon During suggests that Foucault and literature is "an obvious enough conjuncture. " While it may (or may not) be so obvious, the extend to which such a moment keeps from being more antagonistic than cooperative -- which During does not want it to be -- naturally depends upon a 'Foucault' and a 'literature' that are rather specifically represented. North American Foucauldians -- likely conditioned, on one side, by Dreyfus' and Rabinow's purely philosophical Foucault, and on the other, by progenitors of literary appreciation -- will find a different 'Foucault,' if not another 'literature' than the ones currently opposed to each other. The irresistible force of political critique does not confront the immovable object of good taste in Foucault and Literature, as some might expect in such a match-up.

Indeed, as one of its most innovative effects, During's book -- his 'Foucault' combined with his 'literature' -- works to remove the theory/art distinction so that issues like humanism, genius, and canonicity become not so much less real as less urgent and finally less necessary for either literature or theory as reconceived by During. In fact, at key moments in the book the two are not distinguishable, or, at least, not desirably so. For During, the big issues of humanism and taste become the empty residual of representation in a post-enlightenment age that is neither Foucauldian nor literary. The humanism woven into high literature becomes, if in a cursory way, the absent object of both genealogical history and new literary production, an object that somehow provides a basis for joining the two. 
Foucault and Literature makes the pitch for its unique form of arbitration first, and primarily, by presenting a literary history of Foucault's work. Again, it is a self-proclaimed revision of what Foucauldians, especially Americans, have probably come to accept: that is, the four part division of Foucault's work into the 'psychological' positivism (50s to early 60s); the 'archeological' structuralism (the rest of the 60s); the most popular 'genealogical' work (70s); and, finally, the most confusing (most 'postmodern') work on ethics (late 70s to 80s). In a move that is itself Foucauldian (what is a history if not productive?), During makes a shift of interest to the role of literature in Foucault that enables him to produce, rather, a two part history: Foucault's work moves around the early 70 s from an interest in avant-garde and transgressive writing, to both a consideration of the more local and concrete conditions and effects of specific intellectuals who write, and, if in less distinguished way, to ethics. The two phases are linked in the end by the 'delirium of representation' that belongs equally to Foucault and to literature.

In effect, the 'psychological' and 'archeological' Foucault -- which During taints, as most do, with a little structuralism and positivism -- is combined into a 'transgressive-literary' Foucault. For example, in the first chapter, "Madness," which begins in the rather clever guise of a chronological introduction to Foucault's work that comprises seven of the book's nine chapters, Foucault becomes a specific kind of poet. In a characteristic phrase, During notes that Foucault's early work is "poetic in the sense that it apostrophizes its object: endowing madness with much of the force and aura it claims to derive from it. A will to valorize the others of reason is apparent" (41). During notes, thankfully, that this is the most romantic and least political version of Foucault; but, still, it is important ground work for During in trying to establish the centrality of the literary to Foucault.

More importantly, "the absolute creativity and (existential) freedom" (31) of the insane and of the (french/avant garde) poetic, functions to set up the literary import of archeology, which "belongs itself, if somewhat tenuously, to "'literature'" (114). Archeology (like madness) and aesthetics mingle "as if not having to pass through the thresholds of knowledge as knowledge." Literature has "a slipperiness and freedom so that, potentially at least, it is in aesthetic objects that archeological shifts first appear" (114). These lines are key in that they show, above all, the theoretical-literary allegiances that During is attempting to find.

Not until During begins his account of the 'genealogical' Foucault - -- that is the Foucault less interested in freedom than in politics and power -- do some of the expected tensions between aesthetics and theory begin to get directly addressed. (During is careful, however, to distinguish 'humanist commentary' from 'transgressive' french literary practices in the earlier 
sections of the book.) The second part of his literary history of Foucault begins after the late sixties, still a key shift, but not for the usual and reductive reasons of the student uprisings of Paris, '68. The last two phases of the traditional Foucault, concerned explicitly with governability and techniques of ethical 'self-fashioning,' are vetted and combined to produce a Foucault that can reclaim radically recontextualized notions of "liberty, beauty and risk." This calls forth a problematic of power and power's relationship to aesthetics and agency that is fundamental to questions surrounding a cultural debate that is especially heated in Britain and America: to what extent, for example, does a 'transgressive aesthetic,' the way it can be represented institutionally today, obey the laws of power? how is taste used to produce docile and governable subjects? how do structures of epistemological differentiation -- disciplinary boundaries -- contribute to that other sense of discipline?

These questions are all, rightly, traced by During to Foucault's genealogical turn. More importantly, they provide the occasion for During to make two pivotal moves. The first depends upon a distinction of nationality, namely a separation of literature, as it pertains to the British case, from that of the earlier transgressive (i.e. Foucauldian) literature. During is willing to grant, if in a limited way that the enlightenment ideals of authorship, genius, etc. are intertwined with less benign looking practices such us police surveillance, and factory work. These are at the basis of Foucault's well known essay on authorship. But for During as for Macherey or any number of ideology critics, literature mobilized in the post-humanist sense is that kind of writing which maintains a kind of contradictory space. Literature (beginning now to sound like the kind of writing that comes between Marxist science and mere ideology) can critique the disciplinary society from which it emerges by creating a sense of what Greenblatt (During's favorite Foucauldian) somewhat dubiously refers to as 'resonance' and 'wonder.'

Moll Flanders, for example, can play a dual role of being part of a moral technology and of private amusement dissociated from the public sphere where, at least as During tells it, discipline operates most efficiently (158). This is probably a bit watered down with regards to Foucault, who has been of more use to eighteenth-century cultural studies in showing how the fixed and universal distinction between the public and private, as it first emeged in the enlightenment, in fact, had everything to do with governability; that the sphere of the private as a component of the public is never outside the realm of power; and that power, really, operates most efficiently when we attempt to think outside it. This is, clearly, not to say that all Enlightenment ideals are bad. With regards to apartheid they turn out to be progressive. It is, however, to say -- and During is a little slow to emphasize this -- that with regard to the institutional practices of literature, the enlightenment has fairly little to offer in the name of politics. 
This kind of thinking, which certainly represents one of many Foucaults, marks a certain limit that During, in order to have a literary Foucault, is very clever about responding to. At one level, it becomes important to echo the well known critique of Foucault on the grounds of relativity and presentism (à la Habermas and Peter Dews). But such critiques are not, after all, directed towards the literary-transgressive Foucault, and it is from this angle that During responds to such charges (142-43). During concedes that Foucault's work is particularly inadequate on the question of agency. The perhaps stronger Foucault who suggests that there is no outside from which to conceive of power relations that is not at once a part of them is a Foucault that During wishes to qualify. But he does not, therefore, call for the unfinished project of the enlightenment. By suggesting that reading literature can be linked to the 'aesthetico-ethico' modes of self formation found in the late Foucault -- only without the nihilism -- During, again, tries to find room for a combination of both.

The final two chapters complete this process of negotiation from its other side. Having offered a literary Foucault, chapters eight and nine offer a Foucauldian literature, or more precisely, a genealogical representation of it. For literary scholars, there is a hint of nostalgia here that is less clear in the first part of the book. Granted one returns, after Foucault, to a different literature than the one given traditionally. One returns to a post-humanist literature, as During (and Greenblatt) return to Hamlet as a kind of writing that share the best features of the early 'transgressive' and late 'genealogical' writing of the literary Foucault (209). Clearly, During on Hamlet -- a play that, for him, "explores the border at which continuity, madness and order, life and death, are joined and separated in representing the limits of representation" (209) -- is really During on Foucault. One senses in the post-humanist brand of appreciation and reconciliation, the subtle transformation into equally post-theoretical terrain.

Depending upon which 'Foucault' and which 'literature' one is predisposed to prefer -- and it will no doubt vary from institution to institution, as much as from continent to continent -- During's invitation in Foucault and Literature will be more or less useful. It represents, at the very least, a provocative move in the latest institutional uses of Foucault. It also signals a certain kind of willingness to risk the consequences of trying new relationships and combinations, especially ones that don't fall so neatly on either side of the common debate between theory and art.

\section{Michael Hill}

\section{The Humanities Institute}




\section{E 4341 Library}

SUNY at Stony Brook

NY 11794-3394

Surface Page d'Acceuil/Home Page 